\title{
The case for policy intervention in land use change: a critical assessment
}

\author{
Stefano Pareglio \\ Università Cattolica del Sacro Cuore, Brescia, Italy
}

\begin{abstract}
Recent urbanisation trends are frequently characterised by spatial fragmentation and scatteredness, as urbanised territories are distributed in space at irregular intervals. In this article, it is argued that such irregularities in spatial distribution result, at least in part, from the absence of a specific policy design about land use. Soil, in fact, is a public good, finite and non-reproducible. As such, soil management requires well-defined policies preventing misuse and excessive soil consumption for economic sustainability. The case for policy intervention is discussed in relation to the Italian context. On the one hand, it is argued that a sufficient knowledge of the phenomenon is a fundamental prerequisite for policy design. Accordingly, commonly agreed measures of soil use should be available for the whole country on a territorial level. On the other hand, the causes of soil use change should be identified. In particular, a relevant issue to be addressed is to what extent changes in soil use are driven by actual housing demand and then, in turn, by population growth. There is evidence, in fact, showing that changes in soil use are driven by the demand for real estate investments. Consequently, land use policies are required to take into account the social costs of land transformation.
\end{abstract}

\section{Understanding changes in land use}

As Luigi Einaudi (1959) argued years ago, no decision can be taken, nor can any policy actions be effective without sufficient knowledge of the situation in hand. However, in spite of the public rel-

Correspondence: Stefano Pareglio, Department of Mathematics and Physics, Università Cattolica del Sacro Cuore, via Musei 41, 25121 Brescia, Italy. E-mail: stefano.pareglio@unicatt.it

Key words: sprawl, land use policies, soil protection.

Conference presentation: AISSA Palermo, 2012. Represented society at AISSA: SIDEA - Società Italiana di Economia Agraria.

Received for publication: 6 May 2013.

Revision received: 17 September 2013.

Accepted for publication: 21 September 2013.

(C)Copyright S. Pareglio, 2013

Licensee PAGEPress, Italy

Italian Journal of Agronomy 2013; 8:e26

doi:10.4081/ija.2013.e26

This article is distributed under the terms of the Creative Commons Attribution Noncommercial License (by-nc 3.0) which permits any noncommercial use, distribution, and reproduction in any medium, provided the original author(s) and source are credited. evance involved in the debate, the analyses of the determinants, the effects and the policy responses to the issue of soil consumption are still not grounded on specific measures.

According to Corine land cover (CLC) nomenclature, artificial surfaces are defined as continuous and discontinuous urban fabric (housing areas), industrial, commercial and transport units, road and rail networks, dump sites and extraction sites, but also green urban areas (European Commission, 2011). Furthermore, land take is defined as the increase of artificial surfaces (housing areas; green urban areas; industrial, commercial and transport units; road and rail networks; etc.) over time (European Commission, 2011), whilst soil sealing can be defined as the destruction or covering of soils by buildings, constructions and layers of completely or partly impermeable artificial material (asphalt, concrete, etc.). It is the most intense form of land take and is essentially an irreversible process (European Commission, 2011).

In addition to this difference in interpretation (i.e. land take $v s$ soil sealing), available measures of soil consumption in Italy differ significantly for a number of other reasons. Emiliani (2007) estimated soil consumption for the period 1990-2005 to be $43 \mathrm{~m}^{2}$ per inhabitant per year. Lower estimated values of 11.6 and 10 are found respectively in Berdini (2009), for the years 1995-2006, and by the Italian Geographical Society (SGI, 2009) for the years following the Second World War. Finally, an estimate of 1.5 is reported by the Italian Environmental Protection and Technical Services Agency (Agenzia per la protezione dell'ambiente e $i$ servizi tecnici, APAT) (2005) for the period 1990-2000. In the first case, the overestimation is the result of a computation based on variation of agricultural land, while in the latter case, the underestimation is due to the geometrical resolution of analysed variations, the last based on CLC. It is, however, clear that these different measures of soil consumption are not compatible.

The absence of scientifically reliable and commonly agreed measures is a serious obstacle, even considering the clear prominence of the phenomenon. Despite the uncertainty mentioned above, most realistic estimates (Arcidiacono et al., 2011, 2012) agree on a yearly loss of approximately 40,000 hectares (Ha) of free soil. Land use change is primarily a characteristic of the most accessible and fertile areas of the country, which in turn represent a limited portion of national territory and should be considered, therefore, as a reference for what constitutes effective soil consumption. For instance, in the province of Milan, 35\% of soil is waterproofed. The figure rises to its peaks in the Rho and Legnano areas (50\%) and in territories part of the Milan-Como-Varese triangle (70\%).

This trend in soil consumption does not appear to be declining, with 11.7 daily Ha consumed in Lombardy (1999-2007), 8.4 in Emilia Romagna (2003-2008), 0.8 in Friuli Venezia Giulia (1980-2000) and 0.63 in Sardinia (2003-2008) (Arcidiacono et al., 2012). In addition, soil consumption is involving more and more small and medium size cities, and not just in peripheral areas of urban agglomerations. These are agricultural and rural areas where high levels of per capita consumption are accompanied by low urbanisation (Gallozzi and Guerrieri, 2005; Barberis et al., 2006) based on the experienced correlation between the cost of a resource and the efficiency of its use.

This consolidated trend in soil consumption appears to be only 
weakly related (or altogether unrelated) to demographic trends: 509 $\mathrm{m}^{2}$ per inhabitant in Lombardy (1999-2007), 548 in Emilia Romagna (2003-2008), 4.148 in Sardinia (2003-2008), while in Friuli Venezia Giulia soil consumption has accompanied a decline in population (Arcidiacono et al., 2012).

Furthermore, soil consumption follows local dynamics, sometimes resulting in alarming spatial patterns, the threat of which clearly emerges when the many environmental, economic and social functions the scarce and irreproducible soil is asked to perform are examined. Among other things, it is worth thinking about water and carbon cycles, mass and energy balance, biodiversity and ecological connections, agricultural production, landscape design and local identity. [For a review of the topic see Blum et al. (2006) and EEA (2006) and, in the case of urban soil, Barberis (2005) and Scalenghe and Marsan (2009).] It is also important to remember that the environmental effects of soil sealing extend beyond areas that are actually waterproofed, for instance in the case of infrastructure (EEA, 2001), and that the ecological functionality of soil is constantly under pressure from climate change. [For a survey of effects of climate change and possible responses in terms of risk management and adaptation see Bradley et al. (2005)]. Such typology of soil consumption is frequently the consequence of the takeover of agricultural rent from private individuals, as well as of lack of governance. In many cases, this has produced patterns of urban settlement that are characterised by excessive spread, with mobility primarily based on private transportation which is, therefore, unsustainable. These are the characteristics of socalled urban sprawl. Urban density is the most common but not the only proxy measure (Jaeger et al., 2010a, 2010b) and, in some cases, it is even not the most appropriate (Jaret et al., 2009).

This phenomenon is triggered by economic and social dynamics on a global scale and of historical importance. It links the United States (Bruegmann, 2005) to many European countries and regions (Couch et al., 2007), even when the clear diversity in urban growth phenomena on the global scale is considered (Schneider and Woodcock, 2008). Europe is [...] one of the most urbanised [continents] on earth. Today, approximately $75 \%$ of the European population live in urban areas. [...] More than a quarter of the European Union's territory has now been directly affected by urban land use; by 2020, approximately $80 \%$ of Europeans will be living in urban areas, while in seven countries the proportion will be $90 \%$ or more. [... J Cities are spreading, minimising the time and distances between and in-and-out of the cities. This expansion is occurring in a scattered way throughout Europe's countryside [...]. Urban sprawl is synonymous with unplanned incremental urban development, characterised by a low density mix of land uses on the urban fringe. [...] Historically, the growth of cities has been driven by increasing urban population. However, in Europe today, even where there is little or no population pressure, a variety of factors are still driving sprawl. [...] All available evidence demonstrates conclusively that urban sprawl has accompanied the growth of urban areas across Europe over the past 50 years. Historical trends, since the mid-1950s, show that European cities have expanded on average by 78\%, whereas the population has grown by only 33\%. A major consequence of this trend is that European cities have become much less compact. The dense enclosed quarters of the compact city have been replaced by free standing apartment blocks, semidetached and detached houses. [...J Trends towards new low density environments are also evident in the space consumed per person in the cities of Europe during the past 50 years which has more than doubled. In particular, over the past 20 years the extent of built-up areas in many western and eastern European countries has increased by $20 \%$ while the population has increased by only $6 \%$ [...] (EEA, 2006).

In Europe, the uncoupling of population growth and the increase in soil used for construction has already been highlighted in community projects such as MURBANDY (Monitoring Urban Dynamics) and
MOLAND (Monitoring Land Use Dynamics). These projects have shown not only a general declining trend in urban density, but also the roles played by the settlement of productive and commercial activities and the development of transport systems in determining soil consumption (EEA, 2002; Kasanko et al., 2006).

Europe refers to a territory which, to a large extent, has been characterized as a polycentric mega-city region (Hall, 2004; Hall and Pain, 2006). This is a new mode of urban organisation that has been initially observed in Asia, in particular in the deltas of the Yangtze and Pearl rivers, in the area of Jakarta, and in the Tokyo-0saka corridor. It is now being reproduced in Europe with similar characteristics as a consequence of the long-lasting and continuing process of decentralisation from large urban agglomerations to small, sometimes new, urban sites, more or less in the same neighbourhood.

The mega-city-region is a new urban form: a series of anything between twenty and fifty towns, physically separate but functionally networked, clustered around one or more larger central cities, and drawing enormous economic strength from a new functional division of labour. These places exist both as separate entities, in which most residents work locally and most workers are local residents, and as parts of a wider functional urban region connected by dense flows of people and information along motorways, high-speed rail lines and telecommunication cables. It is no exaggeration to say that this was the emerging urban form at the end of the twentieth century, and that it will prove pervasive in the twenty-first (Hall and Pain, 2006).

This discussion emphasises the extent to which reliable information about changes in land use is the necessary basis for an analysis of soil consumption and, more specifically, of the effectiveness of the measures implemented, allowing citizens to call government policy makers at different levels into account for their actions. This information must be made available in order to develop a more rational and less ideological approach to the problem.

Indeed, it is completely legitimate to discuss how to interpret soil consumption, even taking into careful consideration the policy actions to be undertaken. In particular, does soil consumption follow soil use change or effective physical transformation? And should permeable areas, including sealed areas such as urban parks, be considered consumed? Does consumption originate from infrastructure abutments for collective mobility comparable to that of a building? How is it possible to disentangle the sprawl phenomena from the general low urban density that results from conscious decision making? How can sufficient space be given to public services? How can sufficient space be given to green areas? Indeed, green spaces are useful: i) to limit the effects of urban heat islands; ii) to contain energy consumption for cooling in summer periods; iii) to improve the acoustic environment; iv) to enhance the urban landscape; and v) to generate recreational, cultural, social and even psychological benefits (Chiesura and Mirabile, 2008).

The decision to adopt diversified land use classification systems unrelated to the CLC seems to be far less appropriate, even though this is already consolidated in Europe and in some Italian regions.

To provide a basis for shared understanding, it is important to arrange an official national (and regional) inventory of use. In Italy, there are already some interesting examples. Unfortunately, they have been created with different aims and ranges, and as such, they are not directly comparable in terms of adopted classifications and a number of other characteristics, such as time period, territorial cover, detectable units, systematic updates, types of base data (aerial or satellite image, digital cartography, numerical data or other), use of sampling, adherence to international laws and recommendations, and even certification of the quality of the output (Arcidiacono et al., 2011, 2012).

In other words, a more precise understanding of land use change 
can be considered as a common heritage, even for reasons related to economies which can be realized through synergies of different projects. From this perspective, the project Pilot studies on the provision of harmonized land use/land cover statistics. Synergies between LUCAS and the Italian national systems has recently been announced by the Italian National Statistics Institute (ISTAT) and will run for a period of 18 months in close collaboration with other research institutes, namely Institute for Research and Environmental Protection (ISPRA), National Institute of Agricultural Economics (INEA) and Ministry of Agricultural, Food and Forestry Policies (MiPAAF). This, in fact, represents a first, essential step in co-ordinating the different inventories.

\section{Analysing determinants, interpreting results}

The focus on the determinants of soil consumption means that policy actions can be based on causes rather than on outcomes.

Such determinants can be generally identified in the continuous takeover of agricultural rent. For instance, between 1994 and 2007, 11 million new rooms were constructed in Italy while the population grew by approximately 2.7 million. In addition, it is important to consider that most of this growth is nominal, since the change in official figures is largely due to the regularisation of immigrants that came into force in 2002. The trend is related to: i) the favourable economic situation and the availability of credit at low interest rates (at least up to mid-2007, before the outbreak of the so-called housing bubble); ii) the structural difference in the prices of urban and extra-urban houses (the latter being a key element in the decision-making process of new generations of households); iii) new modes of production and distribution; iv) the increasing residential demand coming from immigrants; v) the increase in commuting for work or study purposes; vi) the frequent search for better residential conditions; and vii) the increasing demand for second houses for vacation purposes.

In addition, at least in Italy, the historical disposition toward real estate investments has contributed enormously. In recent years, an important incentive has also come from tax relief measures for business properties and, even more so, from the possibility given to local governments of using urbanisation charges to cover current expenditures as a partial compensation for the reduction in central government transfers and the loss of income due to the abolition of the municipal property tax. This choice has, in fact, forced local administrations to face a tragic dilemma: either to continue offering services to the community or to consume territory, probably in competition with other neighbouring administrations.

In this complex and general framework, the scarce capacity of agricultural areas should be considered with respect to settlement pressures.

In Italy, a population growth of approximately $10 \%$ in the period 1971-2010 has been accompanied by a reduction in usable agricultural area (UAA) of around 28\% ( $>5$ million $\mathrm{Ha}$ ) (MIPAAF, 2011). Figure 1 shows detailed data for the period 1974-2010. These show a general positive trend in population growth accompanied by a decline in UAA. It can also be seen that exactly when the population starts to grow most rapidly, UAA experiences the most rapid fall toward the current values.

Obviously, not all cases concern soils that have been sealed. Some cases might be the result of the long-lasting crisis in the agricultural sector that is facing structural problems due to both economic challenges and generational turnover.

Furthermore, the continuous loss of land for agricultural use is no longer compensated for, as it was in the past, by increased agricultur- al productivity, as for most types of farming this has now stabilised. Finally, considering the evolution in consumption, self-provision in agriculture is experiencing a considerable decline, reaching a current value of $80-85 \%$ (MIPAAF, 2011).

The situation described for Italy most resembles a structural deficit of agricultural soil or, to use the terminology of the Sustainable Europe Research Institute (SERI), land import. The difference between agricultural land necessary to produce food, fibre and fuel consumed by the population and the UAA actually used (currently approx. 12 million $\mathrm{Ha}$ ) is estimated at 49 million Ha (Lugschitz et al., 2011).

It should not be forgotten that also land used for agriculture is subject to significant environmental pressures which follow intensification of agricultural production and zootechnics, farming specialisation (absence of any crop rotation), physical degradation of soil structure due to more mechanised approaches to farming, massive use of chemical products, and loss of organic substance and biodiversity.

All this suggests the importance of investigating not only the determinants of soil consumption, but also the overall consequences of the phenomenon, which certainly cannot be incorporated into the measure of soil sealing, which is irreversible (or at least reversible only to a very small extent), transformation of agricultural and natural soil into waterproofed land (or with small permeability) designated to new settlements and, in most cases, to be used for residential, productive, commercial and infrastructural purposes.

In other words, it is important to account for, on the one hand, consumption efficiency and, on the other hand, the general consequences on a local level.

Consumption efficiency refers to the loss of ecological functionality in areas not sealed but still influenced by transformation. Admittedly, it is difficult to define an optimal urban density in which the term optimal should always be considered with some degree of arbitrariness. But it is still recognised that compact cities are, in general, more efficient. Evidence shows that per capita energy consumption and $\mathrm{CO}_{2}$ emissions are both negatively correlated with population density (EEA, 2006). This is interpreted as the result of the increase in efficiency generated by the mobility of people and goods, and by a different approach to the provision of services (Hortas-Rico and Solé-Ollé, 2010).

The general consequences on a local level are depend on the intrinsic quality of consumed soil and on the environmental sustainability of territorial morphologies originating from urbanisation: i.e. compact

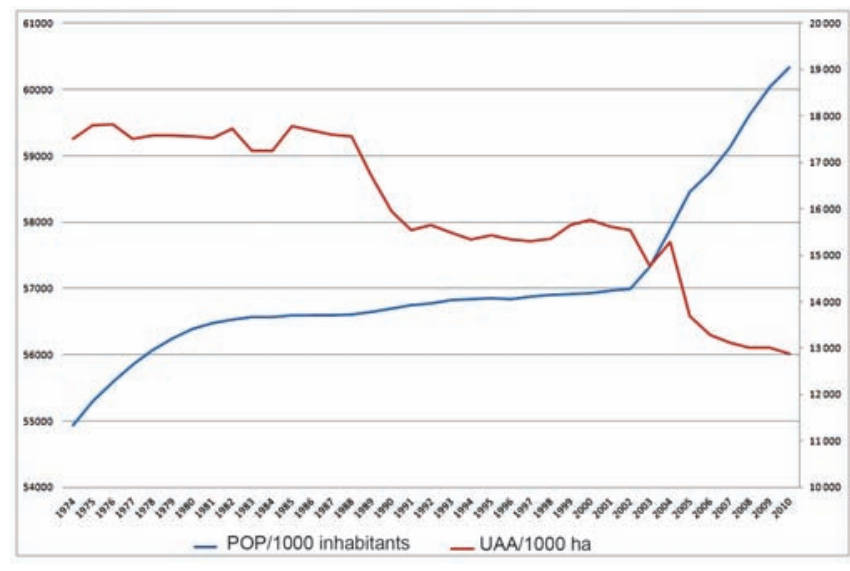

Figure 1. Trends in population (POP) growth and usable agricultural area (UAA) in Italy, 1974-2010. Source: Author's elaboration based on Eurostat. 
expansion of existing cities, variously defined urban fringes, linear strips along main road axes, clusters of buildings in the proximity of super-urban attractors such as stadiums, expos, congress centres, commercial centres, stations, theme parks, conurbations and undefined settlement points. For instance, morphologies with different densities and functionalities that are seemingly connected and sometimes conflated follow a path drawn by radical changes in modes of production, of transportation, and logistical dynamics. It is no longer a path that is exclusively shaped by the rigid rule of agricultural rent. As such, these morphologies appear more or less sustainable (Jenks and Dempsey, 2005) based on the effect they can have on mobility, on the provision of services, on ecological imbalance, on water, on landscape, on agricultural activity, on the quality of life for local communities (Frumkin, 2002), and even on the social dimension. As far as this last social aspect is concerned, admittedly, the relationship between urban sprawl and social capital still appears controversial (Nguyen, 2010). In cases in which social interaction and group involvement are measured, such relationships have even been shown to be positive (Brueckner and Largey, 2006). Once systematic quantitative information on land use change is available, it is possible to evaluate, using a qualitative or parametric approach, the direct and indirect impacts induced by these changes. Likewise, it can then be investigated the effect of economic conjuncture or it can be analysed the incidence of spatially heterogeneous features of land parcels such as clustering, regulation, accessibility to urban centres, soil quality, size and interactions among neighbouring landowners' land use decisions due to external influences on land use change (Irwin and Bockstael, 2004).

Consequently, having the correct information can be considered the starting point from which to define effective policy actions but also to promote a deeper awareness of the functions performed by soil, moving beyond a debate often confined to an ideological opposition that leads nowhere.

\section{Policies and actions to be promoted}

Based on this discussion, the relevant question that needs to be answered now concerns what instruments should be used to immediately and radically deal with the inefficient use of free soil in such a way as to obtain, in the medium term, a positive balance between regenerated and consumed soil.

The answer can be found by considering the essential fact that the soil, by definition a private good, fulfils functions of public interest.

According to economic theory, public and private goods are identified on the base of characteristics related to production and consumption: rivalry and excludability (Samuelson, 1954). Rivalry is when consumption of a good by one individual prevents, in total or in part, consumption by other individuals. Excludability concerns the possibility to implement technical or economic practices aimed at impeding consumption by non-paying individuals.

Only pure public goods and services are non-rival and non-excludible. This is a simple theoretical distinction, but practical applications become problematic for at least two reasons.

The same economic theory that has highlighted other characteristic elements of public goods has not been able to provide classification systems that are any different from that originally proposed by Samuelson. This is the case of collective goods (Olson, 1965), in which the role played by government is emphasised, and the case of social wants (Musgrave, 1987) in which the inalienable rights of people, such as health and instruction, are emphasised.

It is clear that real goods cannot be easily associated uniquely to either category. For purposes of classification, approaches based on degrees of affinity, such as those used in fuzzy logic (Zadeh, 1965) would probably be more appropriate than a strict dichotomy.

Such barriers in definition are evident when it comes to classifying environmental services and, hence, soil consumption. Certainly the relative scarcity, the fruition level, the set of laws and rules regulating its use, the historic and geographical, and even cultural, social and political framework, can effectively condition the outcome of classification. Nonetheless, it can be asserted that, in general, soil belongs to the category of public goods, at least based on an economic approach to classification.

Beyond the definition of specific characters of the good, it is important to focus also on the so-called externalities, i.e. the effects related to good's consumption which are partially registered (or not registered at all) by the market. An externality is present whenever some individual's (say A's) utility or production relationships include real (that is, nonmonetary) variables, whose values are chosen by others (persons, corporations, governments) without particular attention to the effects on A's welfare. [...J The decision maker, whose activity affects others' utility levels or enters their production functions, does not receive (pay) in compensation for this activity an amount equal in value to the resulting (marginal) benefits or costs to others' (Baumol and Oates, 1988).

From this perspective, soil again turns out to be a good example. One only has to remember to what extent the several environmental functions performed by soil are limited or cancelled by soil sealing without there being any economic reward for the damage caused. This is the case of fractioning natural habitats and of the interruption of ecological connections that are necessary to preserve biodiversity, as well as the deep alteration of water and carbon cycles.

Attention should also be paid to the socio-economic externalities related to inefficient use of soil. Land is the primary resource in agriculture: therefore, soil sealing threatens the socio-economic development of rural areas, with rural communities not receiving adequate compensation for the loss. Consequently, the economic and social imbalance between urban and rural territories is expected to widen.

From a cultural perspective, land is the essential component of landscape, to which historic and social heritage are closely related, as well as the cultural identity of the communities, the value of which should be recognised and should be considered worthy of protection.

Whether one considers soil a partially public good or wants to evaluate the externalities related to soil consumption (Brueckner, 2000, 2001), market signals, and in particular the price system, are not capable of directing role-players towards a type of economic behaviour that results in an optimal and, hence, economically efficient, allocation of available resources.

Consider, for instance, the case of soil consumption when the price of soil is fixed below its total economic value, not accounting for either real scarcity in the long term or negative externalities related to its use. The soil will be used in a larger proportion than that resulting from efficient conditions. Such market failure (Bator, 1958; Stiglitz, 1989) requires public intervention in order to give goods and services a value which they do not otherwise have, or, in some other cases, to correct prices when these do not reflect total economic values (Freeman, 1993) by internalizing externalities not measured by the market (Siebert, 1987): direct, indirect, or acting either on a local or wider scale, including those appearing only in the long term.

The loss of economic value related to inefficient land use, measured by the difference between the total economic value of land and its actual market price, cannot be easily (or at least unambiguously) calculated because of the different social, cultural and institutional factors influencing the real economic value of land in the long term and for a specific context.

In fact, public intervention should not only aim to equilibrate land markets toward efficiency, because although efficiency is easy to con- 
ceptualise, when it comes to environmental resources it is difficult to measure and monitor. Public intervention is also expected to promote equity and, in cultural terms, to ensure that the relevance of soil-related actions is recognised by the public at large, with particular attention being paid to the links between soil and its physical, social and cultural environment. On an institutional level, public intervention is considered to be necessary to reinforce the local identity and hence to protect soil as this is one of its most important components. In practice, this requires a more careful evaluation of monetary and nonmonetary long-term effects related to soil-use change.

This theoretical discussion asks for public regulation of soil use. Clearly, at this stage, some relevant issues are only marginally considered; these are related to market distortions after intervention, or to equity in use, or to the excessive simplification implicit in the assumption that environmental goods and services are commodities represented by their price (Pareglio, 2011).

Regulation might be instituted by using policy instruments of the command and control type, modifying the structure of either rights of use or economic rights (charges, subsidies, or tradable permits) directly influencing the price system (Pearce and Turner, 1990; see Nuissl and Schroeter-Schlaack, 2009, for the case of soil consumption in Germany).

Such a reform, the formulation of which can be related to the neoclassical economic mainstream, and the execution of which is likely to be influenced by the weight assigned to the relationship between public and private interests, is currently under discussion throughout Europe (Cheshire and Sheppard, 2005; Gennaio et al., 2009; Koomen et al., 2008; Korthals Altes, 2009). One critical point would be, in fact, the effect on housing prices consequent to a restriction of the soil supply (Friedl et al., 2011; Phillips and Goodstein, 2000).

Considering these limitations, it could be of interest to pay attention to the indications coming from the analysis of so called commons, that is goods used by more than one individual with a generally high degree of rivalry but for which excludability remains rather limited. In these cases, both the hypothesis of intervention based on efficiency and grounded on the logic of privatisation, and the hypothesis of authoritarian and state-centred intervention present clear obstacles to their implementation (Hardin, 1968; Ostrom, 1990). In other words, it emerges that there are no universal formulas to be applied concerning environmental policy and, hence, soil use regulation. Neither intervention nor a free market can guarantee a better result.

On the contrary, it is important to operate on more than one level, with more stakeholders, more instruments, and with an adequate temporal and institutional vision. Sometimes new, informal and creative solutions should be tested, that can improve democratic procedures by reinforcing inclusiveness in decision making, and even a more adaptable approach should be developed that allows to learn from past experiences (Bengston et al., 2004).

Here, a set of policies aimed at containing soil use will be explored and discussed in an Italian context (for a general survey see Knapp et al., 2007).

First and foremost a fiscal measure is necessary, encouraging renovation and recovery of existing building assets. Sufficient economic incentives for reclaiming polluted sites should be provided by means of a stable and up-to-date normative framework (Swickard, 2008) and this should also encourage the recovery and reuse of abandoned, deteriorated or underused buildings and sites that are no longer functional in terms of safety and security, energy efficiency, social integration or market demand.

Secondly, such a fiscal measure should be accompanied by a more general, and even more complex, reform of purpose taxation, moving beyond the taboo by which land use change is not required to account for, and therefore compensate for, external environmental and social costs determined by residential density, location of settlements, collective mobility, quantity of soil consumed, etc.. Only by fully accounting for these costs, by means of either monetary or non-monetary transfers, when analysing the gains and losses of land transformation, can a real economic disincentive be created, i.e. measures capable of redirecting economic choices and behaviours toward more general, and not only environmental, sustainability.

Finally, all this should, in any case, follow the removal of the serious distortions caused by the use of urbanisation charges to finance the current expenditures of local administrations. This is a measure local authorities have been driven to apply as a consequence of the serious reduction in current transfers from the central administration and the decrease in income following housing tax reform. At the same time, the prominent intervention of two other sources of global distortion should not be forgotten. On the one hand, there should not be such a heavy burden of taxation on the value of existing buildings but this should rather be directed towards the surplus generated by building construction. On the other hand, intervention is needed on planned transformations that are not immediately carried out and which, in fact, represent soil consumption deferred in time. This could be achieved by possibly introducing a deadline after which land owners' rights would expire, similar to what already happens to the rights of public administrations.

From both a cultural and normative perspective, in order to support these actions, soil need to be given a new status, integrating the application of economic leverage.

In this respect, it is important to note that some initiatives are being taken, even though, at the moment, these are proposed in Bills that still have to go through Parliament. In these proposals, and in particular in Bill no. AC/70 Norme per il contenimento dell'uso di suolo e la rigenerazione urbana (Regulations to control land use and urban regeneration; presented March 15, 2013: http://www.camera.it/ leg17/126?idDocumento=0070) measures are suggested to contain land take by economic means, including fiscal charges for the use of natural/agricultural areas and incentives to reuse urbanised sites, and by reducing the duration over time of the building rights assigned to land owners. This latter proposal may prove to be extremely effective, considering that, in the past, town councils have overestimated urban growth and consequently land use changes. Time limits for private building rights are an important tool in the hands of local administrations to review existing land planning.

Only explicit and collective recognition of the fact that soil protection and preservation is of the public interest, such as that provided by a national legal framework, can legitimise and reinforce policies aimed at soil containment by reallocating the costs and benefits of territorial transformation. Such a framework could take its inspiration from the Soil Thematic Strategy (COM 231, 2006) and the Soil Framework Directive (COM 232, 2006).

From an institutional point of view, there needs to be some coherence between administrative competences and the geographical dimension of sprawl. Functions attributed to regional, provincial and local governments need to be revised in observance of the title $V$ of Constitution and Provincial reform (Law 135/2012). In fact, it does not seem possible to design a strategic and effective approach to soil management while decisional power is left in the hands of around 9000 administrations (Oliva, 2008) and while the extent to which soil consumption is driven by international forces and responds to active policies more than to regulatory instruments continues to be neglected.

Among various policies, it is worth remembering the reinforcement of the defence functions played by agriculture, the hierarchical order of territorial structure ensured by transport systems, the development of new economic activities related to natural protected areas, to the landscape and to local identity. 
By and large, curbing soil consumption is necessary but not sufficient in itself, to the extent that the current situation, given all of the inefficiencies discussed above, cannot be considered satisfactory.

On the one hand, to promote adequate change in territorial assets, the concept of creating a balance between new soil consumption and regeneration of existing soil should be introduced and addressed. On the other hand, a reorganisation that makes expected outcomes explicit should be introduced. This should be one that drives towards compactness in areas characterised by urban scattering, with mandatory requirements for new or renewed settlements, at least in terms of minimum density, functional mix, energy standards, environmental performance and integration with collective mobility.

Management of these processes requires a bargaining capacity not always available to local administrations. Such flexibility, although designed to be a rational answer to the evolution of the economic and social framework, has been employed by municipality administrations to extract a share of wealth generated by urban transformation of land. Such an activity can be defined as a socialisation of private rent. In fact, the widespread adoption of this policy has been made possible by various factors: i) the absence of adequate fiscal legislation governing the surplus generated by building activities; ii) the large margins used in the application of existing measures; iii) economic conditions characterised by strict control of administrations' balance sheets; and iv) the absence of any realistic prospect of improvement in the country's financial situation. Therefore, the idea of continuing current policy can not be said to offer much comfort, and not only for its effects on soil consumption.

Also, ordinary government actions need to set more convincing examples. There are, however, some interesting experiences on an EU level (European Commission, 2011) and also on a national level in Italy (especially in legislative proposals generated by the national parliament and regional councils). These include preventive ecological compensation, reuse and ecological regeneration of soil, building densification, diversification, mandatory territorial performances (especially in terms of minimum density and its relation to collective mobility), strategic localisation of functions and services, care of how urban areas are organised (also in relation to adjacent land), the relationship between urban areas with semi-urban and rural ones, practices oriented to urban poly-centrism, collective mobility management on a territorial scale, integration and links to free areas.

Finally, even recognising that there is a wide range of possible solutions, it is worth highlighting significant differences, such as those related to the definition, measurement, classification, flexibility and mode of controlling permeability indices (if they exist) for areas subject to transformation. These differences lead us to conclude that, in this country, this issue has still not received sufficient attention.

\section{Conclusions}

This paper has attempted to emphasise the extent to which reliable and commonly shared knowledge of soil consumption might represent an essential starting point to govern a phenomenon of enormous consequence for both present and future generations. It has also clarified how soil containment policies are an important challenge for local authorities and for the disciplines involved, especially in a context in which private and public resources are scarce. Above all, it has highlighted how containment of soil sealing requires crucial innovation in modes of production and consumption, and in lifestyles. This issue should, therefore, be debated in a rational way, moving beyond ideological debate and demonstrating real willingness for change.

\section{References}

APAT (Agenzia per la protezione dell'ambiente e i servizi tecnici), 2005. La realizzazione in Italia del progetto europeo CORINE Land Cover 2000. Rapporti, 36. APAT, Roma, Italy. Available from: http://www.apat.gov.it

Arcidiacono A, Di Simine D, Oliva F, Pareglio S, Pileri P, Salata S, 2011. Rapporto 2010 - Centro di Ricerca sui Consumi di Suolo. INU Edizioni, Roma, Italy.

Arcidiacono A, Di Simine D, Oliva F, Pareglio S, Pileri P, Salata S, 2012. Rapporto 2012 - Centro di Ricerca sui Consumi di Suolo. INU Edizioni, Roma, Italy.

Barberis R, 2005. Consumo di suolo e qualità dei suoli urbani. pp 703729 in APAT (Agenzia per la protezione dell'ambiente e i servizi tecnici), Qualità dell'ambiente urbano - II Rapporto APAT. APAT, Roma, Italy. Available from: http://www.apat.gov.it

Barberis R, Di Fabbio A, Di Leginio M, Giordano F, Guerrieri L, Leoni I, Munafò M, Viti S, 2006. Impermeabilizzazione e consumo dei suoli nelle aree urbane. pp 631-649 in APAT (Agenzia per la protezione dell'ambiente e i servizi tecnici), Qualità dell'ambiente urbano - III Rapporto APAT. APAT, Roma, Italy. Available from: http://www.apat.gov.it

Bator FM, 1958. The anatomy of market failure. Q. J. Econ. 72:351-79.

Baumol WJ, Oates WE, 1988. The theory of environmental policy. Externality, public outlays and the quality of life. Cambridge University Press, Cambridge, UK.

Bengston DN, Fletcher J0, Nelson KC, 2004. Public policies for managing urban growth and protecting open space: policy instruments and lessons learned in the United States. Landscape Urban Plan. 69:271-86.

Berdini P, 2009. Il consumo di suolo in Italia: 1995-2006 (mimeo). Available from: http://archivio.eddyburg.it/article/articleview/14222/1/164

Blum WEH, Warkentin BP, Frossard E, 2006. Soil, human society and the environment. In: W.E.H. Blum, B.P. Warkentin, E. Frossard (eds) Function of soils for human societies and the environment. Special Publications 266. Geological Society, London, UK, pp 1-8. Available from: http://sp.lyellcollection.org/content/266/1/1.full.pdf

Bradley RI, Moffat A, Vanguelova E, Falloon P, Harris J, 2005. The impact of climate change on soil functions. Defra Project SP0538. Available from: http://www.defra.gov.uk

Brueckner JK, 2000. Urban sprawl: diagnosis and remedies. Int. Regional Sci. Rev. 23:160-71.

Brueckner JK, 2001. Urban sprawl: lessons from urban economics. In: W.G. Gale, J.R. Pack (eds) Brookings-Wharton papers on urban affairs. Brookings Institution, Washington, DC, USA, pp 65-89.

Brueckner JK, Largey AG, 2006. Social interaction and urban sprawl. CESifo Working Paper 1843. Available from: http://www.cesifogroup.de

Bruegmann R, 2005. Sprawl. A compact history. University of Chicago Press, Chicago, IL, USA.

Cheshire PC, Sheppard SC, 2005. The introduction of price signals into land use planning decision-making: a proposal. Urban Stud. 42:647-63.

Chiesura A, Mirabile M, 2008. La multifunzionalità della natura in città. pp 19-23 in APAT (Agenzia per la protezione dell'ambiente e i servizi tecnici), Qualità dell'ambiente urbano - IV Rapporto APAT. Focus su "La natura in città". APAT, Roma, Italy. Available from: http://www.apat.gov.it

Couch C, Petschel-Held G, Leontidou L, 2007. Urban sprawl in europe: landscape, land-use change and policy. Blackwell, Oxford, UK.

EEA (European Environment Agency), 2001. Towards spatial and terri- 
torial indicators using land cover data, Technical Report, 59. EEA, Copenhagen, Denmark. Available from: http://www.eea.europa.eu

EEA (European Environment Agency), 2002. Towards an urban atlas. Assessment of spatial data on 25 European cities and urban areas. Environmental Issue Report, 30. EEA, Copenhagen, Denmark. Available from: http://www.eea.europa.eu/publications/environmental_issue_report_2002_30

EEA (European Environment Agency), 2006. Urban sprawl in Europe: the ignored challenge. Report 10. EEA, Copenhagen, Denmark. Available from: http://www.eea.europa.eu/publications/eea report_2006_10

European Commission, 2011. Report on best practices for limiting soil sealing and mitigating its effects. DG Environment, Technical Report 50. Available from: http://ec.europa.eu/environment/ soil/sealing.htm

Einaudi L, 1959. Prediche inutili. Vol. 3. Einaudi, Torino, Italy.

Emiliani V, 2007. Enorme consumo di suolo, ma emergenza-casa. Report presented at meeting "Paesaggio italiano aggredito, che fare?", Roma 25 october 2007 (mimeo). Available from: http://archivio.eddyburg.it/article/articleview/9974/0/99/

Freeman AM III, 1993. The measurement of environmental and resource values: theory and methods (II ed.). RFF Press, Washington, DC, USA.

Friedl B, Koland 0, Steininger KN, 2011. Urban sprawl and policy responses: a general equilibrium analysis of residential choice. J. Environ. Plan. Manage. 54:145-68.

Frumkin H, 2002. Urban sprawl and public health. Public Health Report 117:201-17.

Gallozzi PL, Guerrieri L, 2005. L'espansione delle aree urbane nel decennio 1990-2000: un'analisi dei dati europei a confronto con la situazione italiana, in APAT (Agenzia per la protezione dell'ambiente e i servizi tecnici), Qualità dell'ambiente urbano - II Rapporto APAT. APAT, Roma, Italy, pp 689-702. Available from: http://www.apat.gov.it

Gennaio M, Hersperger AM, Buergi M, 2009. Containing urban sprawl. Evaluating effectiveness of urban growth boundaries set by the Swiss Land Use Plan. Land Use Policy 26:224-32.

Hall P, 2004. Is the Greater South East a Mega-City Region?, Essay commissioned by Institute for Public Policy Research (IPPR). IPPR Seminar, London, UK. Available from: http://www.ippr.org/ uploadedFiles/research/projects/Commission_on_Sustainable_De velopment_in_the_South_East/Peter\%20Hall\%201.pdf

Hall P, Pain K, 2006. The polycentric metropolis: learning from megacity regions in Europe. Earthscan, London, UK.

Hardin G, 1968. The tragedy of the commons. Science 162:1234-48.

Hortas-Rico M, Solé-Ollé A, 2010. Does urban sprawl increase the costs of providing local public services? Evidence from Spanish municipalities. Urban Stud. 47:1513-40.

Irwin EG, Bockstael NE, 2004. Land use externalities, open space preservation, and urban sprawl. Reg. Sci. Urban Econ. 34:705-25.

Jaeger JAG, Bertiller R, Schwick C, Cavens D, Kienast F, 2010a. Urban permeation of landscapes and sprawl per capita: New measures of urban sprawl. Ecol Indic. 10:427-41.

Jaeger JAG, Bertiller R, Schwick C, Kienast F, 2010b. Suitability criteria for measures of urban sprawl. Ecol Indic. 10:397-406.

Jaret C, Ghadge R, Reid LW, Adelman RM, 2009. The measurement of suburban sprawl: an evaluation. City Commun. 8:65-84.

Jenks M, Dempsey N, 2005. Future forms and design for sustainable cities. Architectural Press, Oxford, UK.
Kasanko M, Barredo JI, Lavalle C, McCormick N, Demicheli L, Sagris V, Brezger A, 2006. Are European cities becoming dispersed? A comparative analysis of 15 European urban areas. Landscape Urban Plan. 77:111-30.

Knaap GJ, Hacco HA, Clifton KJ, Frece JW, 2007. Incentives, regulations and plans: the role of States and Nation-States in smart growth planning. Edward Elgar Publishing, Cheltenham, UK.

Koomen E, Dekkers JEC, van Dijk T, 2008. Open space preservation in the Netherlands: Planning, practice and prospects. Land Use Policy 25:361-77.

Korthals Altes WK, 2009. Taxing land for urban containment: Reflections on a Dutch debate. Land Use Policy 26:233-41.

Lugschitz B, Bruckner M, Giljum S, 2011. Europe's Global Land Demand. A study on the actual land embodied in European imports and exports of agricultural and forestry products. Sustainable Europe Research Institute (SERI), Vienna, Austria. Available from: http://www.foeeurope.org

MIPAAF (Ministero delle Politiche Agricole, Alimentari e Forestali), 2011. Costruire il futuro: difendere l'agricoltura dalla cementificazione. Perdita di terreni agricoli, approvvigionamento alimentare e impermeabilizzazione del suolo (mimeo). Available from: http://www.politicheagricole.it

Musgrave RA, 1987. Merits goods. In: J. Eatwell, P. Milgate, P. Newman (eds) The new Palgrave's dictionary of economics. Macmillan, London, UK.

Nguyen D, 2010. Evidence of the impacts of urban sprawl on social capital. Environ. Plan. B 37:610-27.

Nuissl H, Schroeter-Schlaack C, 2009. On the economic approach to the containment of land consumption. Environ. Sci. Pol. 12:270-80.

Oliva F, 2008. Il nuovo piano. Urbanistica Informazioni 216:63-6.

Olson M, 1965. The logic of collective action. Public goods and the theory of groups. Harvard University Press, Cambridge, MA, UK.

Ostrom E, 1990. Governing the commons. The evolution of institutions for collective action. Cambridge University Press, Cambridge, UK.

Pareglio S, 2011. L'ambiente conteso, tra prezzo e valore. In: P.L. Malavasi (a cura di) L'ambiente conteso. Vita e Pensiero ed., Milano, Italt, pp 41-51.

Pearce DW, Turner RK, 1990. Economics of natural resources and the environment. Harvester \& Wheatsheaf, London, UK.

Phillips J, Goodstein E, 2000. Growth management and housing prices: the case of Portland, Oregon. Contemp. Econ. Policy 18:334-44.

Samuelson PA, 1954. The pure theory of public expenditure. Rev. Econ. Stat. 36:350-6.

Scalenghe R, Marsan FA, 2009. The anthropogenic sealing of soils in urban areas. Landscape Urban Plan. 90:1-10.

Schneider A, Woodcock CE, 2008. Compact, dispersed, fragmented, extensive? A comparison of urban growth in twenty-five global cities using remotely sensed data, pattern metrics and census information. Urban Stud. 45:659-92.

SGI (Società Geografica Italiana), 2009. Rapporto annuale 2009. I paesaggi italiani. Fra nostalgia e trasformazione. SGI, Roma, Italy.

Siebert H, 1987. Economics of the environment. Theory and policy (II ed.). Springer Verlag, Berlin, Germany.

Stiglitz JE, 1989. Economia del settore pubblico. Hoepli, Milano, Italy, pp 115-126.

Swickard TJ, 2008. Regulatory incentives to promote private sector brownfield remediation and reuse. Soil Sed. Contam.17:121-36.

Zadeh LA, 1965. Fuzzy sets. Inf. Control 8:338-53. 